\title{
Creation of 4-Quinolone Thioether and Selenoether Derivatives via Pd-NHC Catalysed Cross-Coupling Reaction
}

\author{
Prasanjit Ghosh \\ Sajal Das*(i) \\ Department of Chemistry, University of North Bengal, \\ Darjeeling, 734013, India \\ Sajal.das@hotmail.com
}

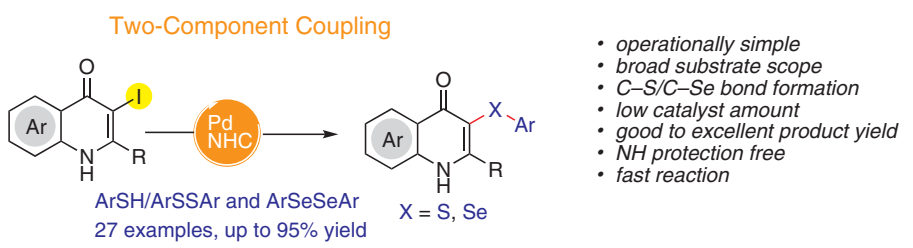

Received: 03.03.2020

Accepted after revision: 27.03.2020

Published online: 12.05 .2020

DOI: 10.1055/s-0039-1690897; Art ID: so-2020-d0008-I

License terms: $(c)(1) \ominus$

(c) 2020. The Author(s). This is an open access article published by Thieme under the terms of the Creative Commons Attribution-NonDerivative-NonCommercial-License, permitting copying and reproduction so long as the original work is given appropriate credit. Contents may not be used for commercial purposes or adapted, remixed, transformed or built upon. (https://creativecommons.org/licenses/by-nc-nd/4.0/)

Abstract Pd-NHC catalysed direct sulfenylation and selenylation of 3iodo-4-quinolones has been developed. This protocol provides an alternative route for the construction of ipso-C-S and C-Se bond formation in 4-quinolones under aerobic conditions.

Key words 4-quinolone, Pd-NHC, sulfenylation, selenylation, crosscoupling

Thioether-functionalised heterocycles are an important class of compounds that are widely found in organic dyes, pharmaceuticals, functional materials, agrochemicals, bioactive products and drugs. ${ }^{1}$ As a result, various methods are available for $\mathrm{C}-\mathrm{S}$ cross-coupling reactions since its first report by Migita et al. in $1978 .^{2}$ A variety of thioethers have been found to have applications in the treatment of various diseases such as Parkinson's, ${ }^{3}$ Alzheimer's, ${ }^{4}$ HIV,${ }^{5}$ and breast cancer. ${ }^{6}$ Similarly, organoselenium compounds have been shown to demonstrate anticancer, antiviral, antitumor, antimicrobial and antioxidant activities. ${ }^{7}$ On account of their hydrogen-bond acceptor and electron-donor properties, organoselenium compounds can dramatically enhance the biological activity of the parent structure. ${ }^{8}$ An example is Ebselen, an organoselenium compound introduced in 1980 as a neuroprotective and antioxidant agent. ${ }^{9}$ Structures of representative biologically active moieties containing diaryl sulfide and selenide moieties are shown in Figure 1. In view of their importance in the field of biology, the development of highly efficient and simple protocols for construction of $\mathrm{C}-\mathrm{S}$ and $\mathrm{C}-\mathrm{Se}$ linkages continues to be of interest. ${ }^{10}$

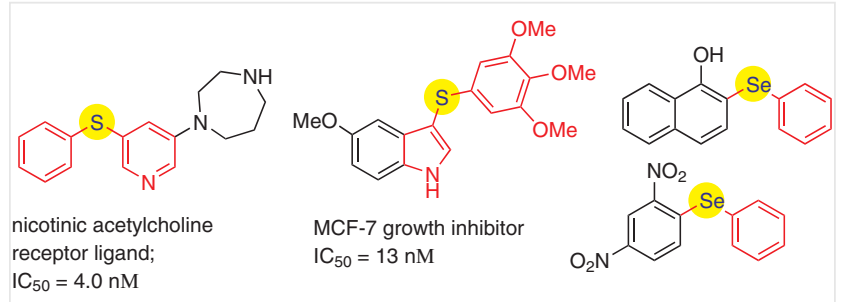

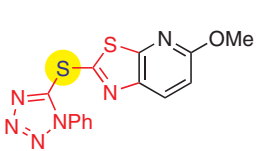

protein tyrosine phosphatase inhibitor
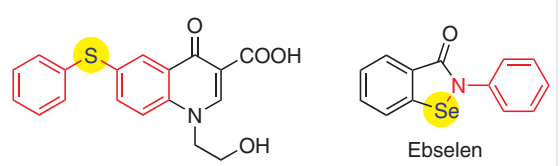

HIV-1 integrease inhibitor $\mathrm{IC}_{50}=4.8 \mu \mathrm{M}$
Figure 1 Representative examples of important biologically active scaffolds containing C-S and C-Se linkages

4-Quinolones frequently feature in pharmaceutical chemistry exhibiting properties such as antibacterial, ${ }^{11}$ antimalarial, ${ }^{12}$ and anticancer activities. ${ }^{13}$ As a consequence, the synthesis of 4-quinolones and their derivatives has received considerable interest and various synthetic procedures are available in the literature. ${ }^{14}$ 3-Aryl- or 3-heteroaryl-substituted quinolones have been widely explored because of their profound biological activities. ${ }^{15}$ However, functionalisation at C-3 of quinolin-4-ones remains a challenging task due to the requirement for $\mathrm{NH}$ prefunctionalisation and protection. Recently, Zhang et al. introduced a technique for thioetherification at C-3 of 4-quinolones via Pd catalysed decarboxylation. ${ }^{16}$ However, this protocol has 

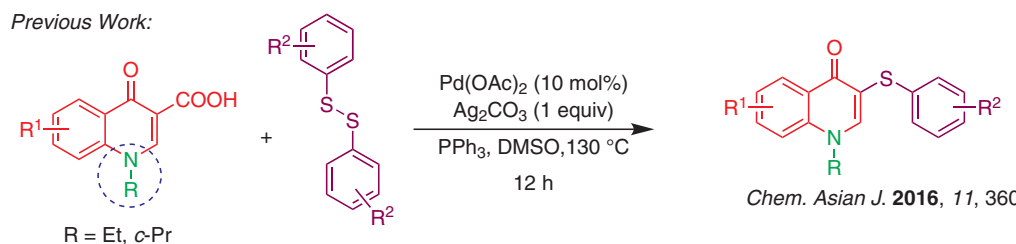

Chem. Asian J. 2016, 11, 360-366

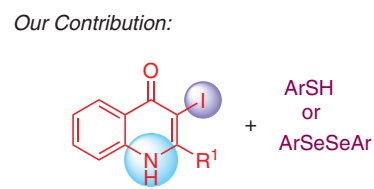

$\mathrm{R}^{1}=\mathrm{Ph}, 4-\mathrm{FC}_{6} \mathrm{H}_{4}, 4-\mathrm{MeOC}_{6} \mathrm{H}_{4}, c-\mathrm{Hex}$,

4- $-\mathrm{ClC}_{6} \mathrm{H}_{4}, 2-\mathrm{MeC}_{6} \mathrm{H}_{4}, 4-\mathrm{NCC}_{6} \mathrm{H}_{4}, c-\mathrm{Pr}$

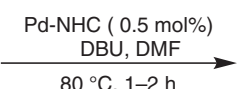

$80^{\circ} \mathrm{C}, 1-2 \mathrm{~h}$

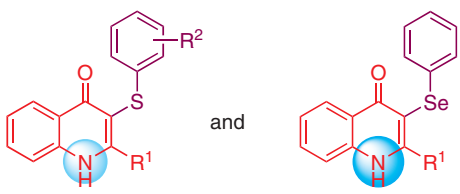

$\mathrm{R}^{2}=\mathrm{Ph}, 4-\mathrm{MeC}_{6} \mathrm{H}_{4}, 4-\mathrm{MeOC}_{6} \mathrm{H}_{4}, 4-\mathrm{FC}_{6} \mathrm{H}_{4}$ 2-Naphthyl, 4- $\mathrm{ClC}_{6} \mathrm{H}_{4}, 2-\mathrm{BrC}_{6} \mathrm{H}_{4}, c-\mathrm{Hex}$

$$
27 \text { examples }
$$$$
\text { up to } 95 \% \text { yield }
$$
$\mathrm{NH}$-protection free

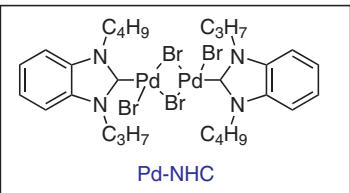

Scheme 1 Previous methodologies for the synthesis of thioether derivatives of 4-quinolone. An approach for the synthesis of C-S and C-Se crosscoupled product is reported herein.

some limitations including harsh reaction conditions, extended reaction times, requiring halogen-substituted 4quinolone substrates and prerequisite $\mathrm{NH}$ protection.

In this area, we have previously reported the regiocontrolled nitration at C-5 and C-7 of 4-quinolones under ambient conditions, ${ }^{17 a}$ regioselective bromination at C-6 and subsequent arylation via Suzuki cross coupling, ${ }^{17 \mathrm{~b}}$ synthesis of 3-aroyl-quinolin-4(1H)-ones from 3-iodo-quinolin$4(1 \mathrm{H})$-ones using carbonylative Suzuki coupling, ${ }^{17 \mathrm{c}}$ carbonylative Sonogashira annulation for the formation of 2-substituted 4-quinolone derivatives, ${ }^{17 \mathrm{~d}}$ synthesis of $\mathrm{N}$-arylated derivatives under ligand free and ambient conditions, ${ }^{17 e}$ and Nal-mediated, metal-free synthesis of thioether and selenoether derivatives. ${ }^{17 \mathrm{f}}$ More recently, we have disclosed a transition-metal free approach for the regioselective C-3 thiocyanation and selenocyanation of the 4-quinolone scaffold. ${ }^{17 g}$ Herein, we disclose a novel, simple and efficient route for $\mathrm{Pd}-\mathrm{NHC}^{18}$ catalysed thioetherification and selenylation of 3-iodo-4-quinolones in good yields under aerobic conditions (Scheme 1). To our knowledge, no such study has been documented before.

Our initial study began with the reaction between 3iodo-2-phenyl-4-quinolone (1a) and thiophenol. After a reaction mixture containing $5 \mathrm{~mol} \% \mathrm{Pd}(\mathrm{OAc})_{2}$ and 2 equiv of DBU in DMF was heated at $80^{\circ} \mathrm{C}$ for $4 \mathrm{~h}$, compound 2a was isolated in $80 \%$ yield (Table 1, entry 1 ). Under identical conditions, when switching to an inorganic base $\left(\mathrm{K}_{2} \mathrm{CO}_{3}\right)$ the yield of product $2 \mathrm{a}$ decreased to $71 \%$. In the presence of $\mathrm{K}_{2} \mathrm{CO}_{3}$, commercially available Pd salts such as $\mathrm{Pd}(\mathrm{OAc})_{2}$, $\mathrm{PdCl}_{2}$, and $\mathrm{Pd}(\mathrm{acac})_{2}$ resulted in similar yields of the crosscoupled product (entries 2-4). Furthermore the yield of the
Table 1 Pd-NHC Catalysed C-S Cross Coupling: Effect of Reaction Parameters ${ }^{\mathrm{a}}$

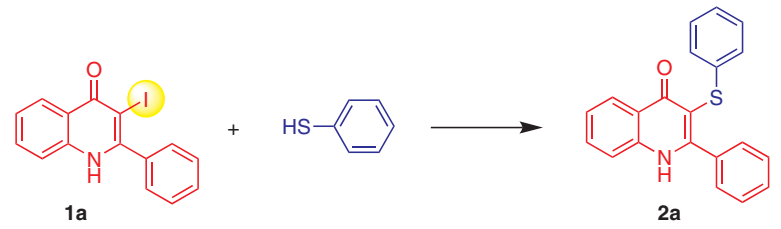

\begin{tabular}{|c|c|c|c|c|c|c|}
\hline Entry & Catalyst (mol\%) & Base & Solvent & $\begin{array}{l}\text { Temp } \\
\left({ }^{\circ} \mathrm{C}\right)\end{array}$ & $\begin{array}{l}\text { Time } \\
\text { (h) }\end{array}$ & Yield (\%) \\
\hline 1 & $\mathrm{Pd}(\mathrm{OAc})_{2}(5)$ & DBU & DMF & 80 & 4 & 80 \\
\hline 2 & $\mathrm{Pd}(\mathrm{OAc})_{2}(5)$ & $\mathrm{K}_{2} \mathrm{CO}_{3}$ & DMF & 80 & 4 & 71 \\
\hline 3 & $\mathrm{PdCl}_{2}(5)$ & $\mathrm{K}_{2} \mathrm{CO}_{3}$ & DMF & 80 & 4 & 73 \\
\hline 4 & $\operatorname{Pd}(\mathrm{acac})_{2}(5)$ & $\mathrm{K}_{2} \mathrm{CO}_{3}$ & DMF & 80 & 4 & 70 \\
\hline 5 & $\mathrm{Pd}\left(\mathrm{PPh}_{3}\right)_{4}(5)$ & $\mathrm{K}_{2} \mathrm{CO}_{3}$ & DMF & 80 & 4 & 53 \\
\hline 6 & Pd-NHC (2) & $\mathrm{K}_{2} \mathrm{CO}_{3}$ & DMF & 80 & 2 & 75 \\
\hline 7 & Pd-NHC (1) & DBU & DMF & 80 & 2 & 83 \\
\hline 8 & Pd-NHC (1) & $\mathrm{Et}_{3} \mathrm{~N}$ & DMF & 80 & 2 & 79 \\
\hline 9 & Pd-NHC (1) & $\mathrm{Cs}_{2} \mathrm{CO}_{3}$ & DMF & 80 & 2 & 52 \\
\hline 10 & Pd-NHC (1) & DBU & 1,4-dioxane & 80 & 2 & 70 \\
\hline 11 & Pd-NHC (1) & DBU & DMF & 40 & 2 & 67 \\
\hline 12 & Pd-NHC (1) & DBU & DMF & $\mathrm{rt}$ & 2 & 59 \\
\hline 13 & Pd-NHC (0.5) & $\mathrm{K}_{2} \mathrm{CO}_{3}$ & DMF & 80 & 2 & 72 \\
\hline 14 & Pd-NHC (0.5) & DBU & DMF & 80 & 2 & 86 \\
\hline
\end{tabular}

a Reaction conditions: 3-iodo-2-phenyl substituted 4-quinolone 0.25 $\mathrm{mmol}, 86 \mathrm{mg}$ ), thiophenol (1.5 equiv, $0.375 \mathrm{mmol}, 41 \mathrm{mg})$, base $(0.5$ $\mathrm{mmol})$.

${ }^{\mathrm{b}}$ Isolated yield after purification by column chromatography. 
anticipated thioether derivative decreased when $\mathrm{Pd}\left(\mathrm{PPh}_{3}\right)_{4}$ was used as catalyst (entry 5). It was found that in the presence of just $2 \mathrm{~mol} \%$ of Pd-NHC catalyst the reaction was complete within $2 \mathrm{~h}$, resulting in the desired cross-coupled product in $75 \%$ yield (entry 6 ). From the optimization table, it is evident that organic bases are more effective. When the cross-coupling reaction was carried out in the presence of 1 mol\% Pd-NHC catalyst, after 2 h, $83 \%$ of the cross-coupled product was isolated when DBU was used as base (entry 7). An similar yield of product was observed using $\mathrm{Et}_{3} \mathrm{~N}$ as base but upon using $\mathrm{Cs}_{2} \mathrm{CO}_{3}$ as base the yield dropped to $52 \%$ (entry 9). Furthermore, we found a direct relationship between yield of cross-coupled product and the reaction temperature. Carrying out the reaction at lower temperatures resulted in lower yields (entries 11,12). After screening the different parameters, we found the combination of Pd-NHC as catalyst, DBU as base and DMF as solvent was optimal. Notably, 0.5 mol\% of Pd-NHC as catalyst afforded 2a in $86 \%$ yield within $2 \mathrm{~h}$ at $80{ }^{\circ} \mathrm{C}$ and served as optimal conditions for this protocol (entry 14).

With the optimised reaction conditions in hand, we explored the substrate scope of both 3-iodo-substituted 4quinolones and variously substituted thiols (Scheme 2). A broad range of thiophenols were reacted with various 3iodo-2-phenylquinolin-4-(1H)ones, affording the corresponding 3-aryl sulfide-4-quinolones in good to excellent yields. Both thiophenols possessing electron-donating and electron-withdrawing groups performed well in this transformation. 4-Fluorothiophenol coupled with 3-iodo-2phenylquinolin-4-(1H)one, resulting in $88 \%$ yield of the desired product 2e. Likewise, 2-thionaphthol furnished moderate to excellent yields (73-86\%; $\mathbf{2 g}, \mathbf{2 k}, \mathbf{2 r}$ ). The greater steric bulk of the naphthyl might play a role in lowering the yield of $\mathbf{2 g}$ and $\mathbf{2 r}$. Next, we examined the influence of various groups at C-2 of the 4-quinolone substrate. It was found that electron-withdrawing groups at C-2 afforded much higher yields in comparison to electron-donating substituents (2h-1, 2m, 2n, 2q, 2r). 2-Cyclohexyl-4-quinolone also proved to be a good coupling partner with 4-chlorothiophenol (2n). The highest yield was obtained when 2-(4-fluorophenyl)-3-iodo-4-quinolone was coupled with 4-fluorothiophenol to give $\mathbf{2 j}$. Surprisingly, 2-(2-methylphenyl)-3iodo-4-quinolone did not afford the corresponding product 2s. The reaction was complete in 1-2 h. Cyclohexanethiol smoothly participated in this sulfenylation reaction and furnished the desired product $\mathbf{2 t}$ in $58 \%$ yield.

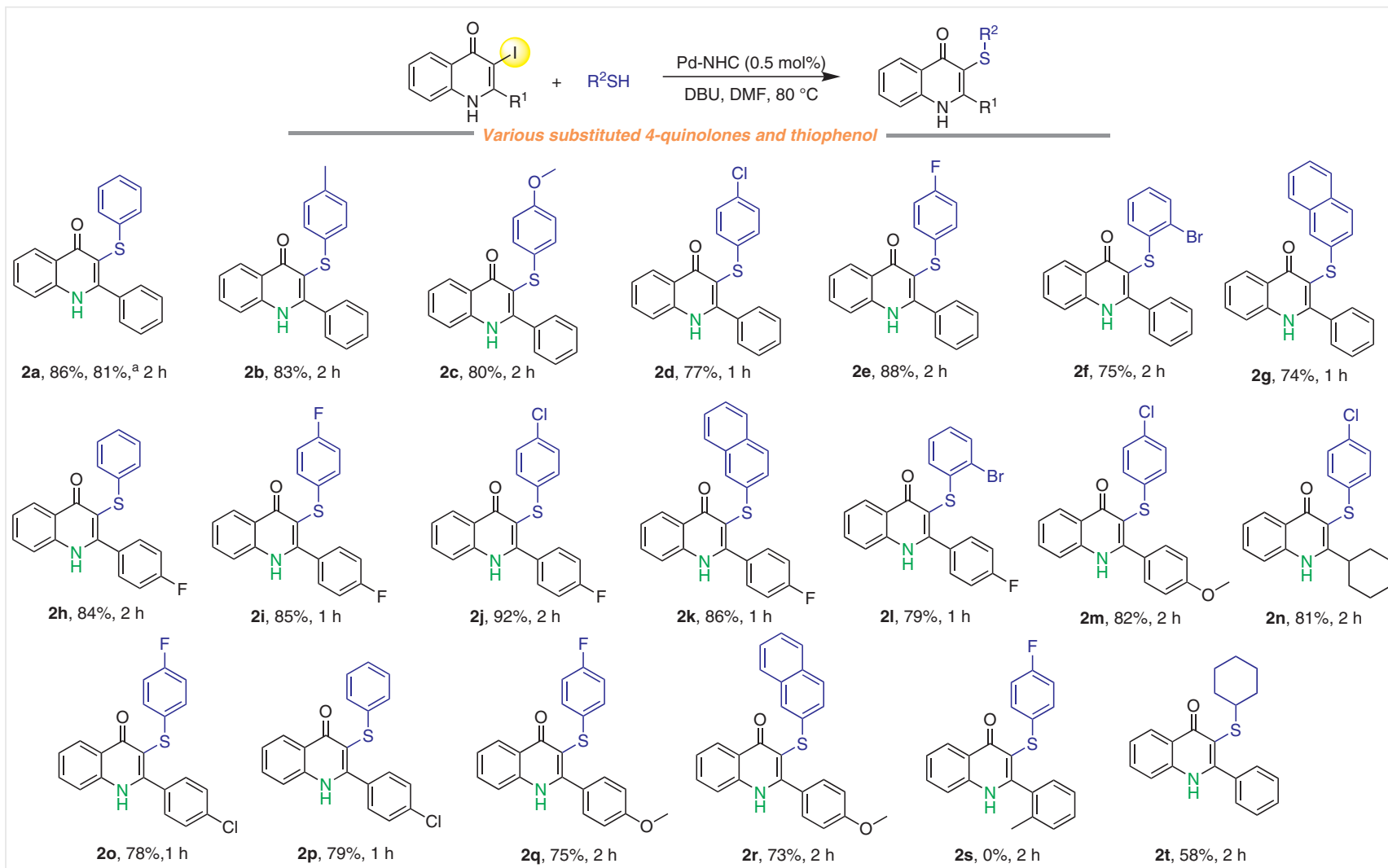

Scheme 2 Substrate scope for the Pd-NHC catalysed thioetherification. Reagents and conditions: 3 -iodo- 2 substituted-4-quinolone (0.25 mmol), thio-

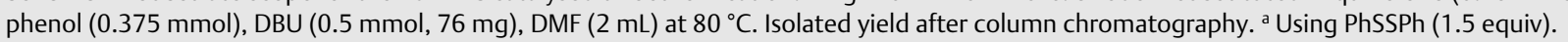


Once the synthesis of various thioethers had been explored, we extend the protocol to the corresponding C-Se cross-coupling between various 3-iodo-2-phenyl-4-quinolones and diphenyl diselenide. Gratifyingly, the methodology proved to be general and we obtained the corresponding products $\mathbf{3 a - g}$ in good to excellent yields (Scheme 3 ). It is important to note that electronic effects of the 2-substituents on the 4-quinolone have a profound impact on the yield of selenide derivatives. 4-Quinolones possessing 2-cyclohexyl and 2-cyclopropyl substituents gave the highest yields of the corresponding products $\mathbf{3 b}$ and $\mathbf{3 f}$, whereas 2aryl substituents possessing electron-withdrawing group such as 4-chloro and 4-fluoro resulted in comparatively low yields of the coupled products $\mathbf{3 c}$ and $\mathbf{3 d}$. The lowest yield was observed for 2-(4-cyanophenyl)-4-quinolone, which furnished only $48 \%$ of the desired coupling product $3 \mathbf{e}$.

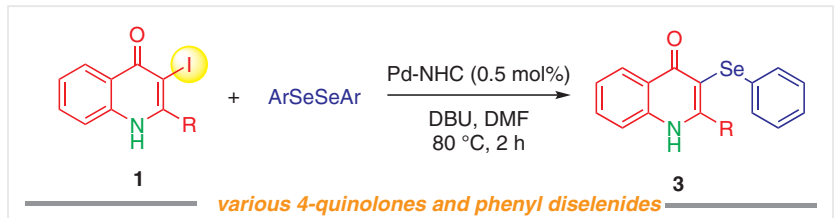

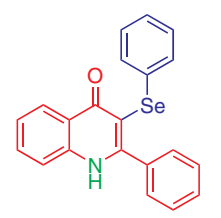

3a, $81 \%$<smiles>O=c1c(-c2ccccc2)c(-c2ccc(F)cc2)[nH]c2ccccc12</smiles>

3d, $78 \%$<smiles>O=c1c([Se]c2ccccc2)c(-c2ccccc2)[nH]c2cc(Cl)ccc12</smiles>

3 g, $75 \%$

Scheme 3 Substrate scope of the Pd-NHC catalysed selenylation. Reagents and conditions: 3 -iodo-2-substituted- 4-quinolone $(0.25 \mathrm{mmol})$, diphenyl diselenide (0.375 mmol), DBU (0.5 mmol, $76 \mathrm{mg})$, DMF ( $2 \mathrm{~mL}$ ) at $80^{\circ} \mathrm{C}$. Isolated yield after purification by column chromatography.

The catalytic cycle for the C-S and C-Se cross-coupling reactions of 4-quinolone derivatives initiated from in situ generation of $\operatorname{Pd}(0)$ species follows the standard pathway and is shown in Scheme 4. Oxidative addition to the 3-iodo2-substituted-4-quinolone affords aryl palladium intermediate A. Next, transmetallation of the thiophenol or organodiselenide with aryl palladium complex $\mathbf{A}$ forms intermediate $\mathbf{B}$ and the desired 3-sulfenylated or 3-selenylated deriv- ative is obtained after reductive elimination with concomitant regeneration of the $\operatorname{Pd}(0)$ species, which enters the next catalytic cycle.

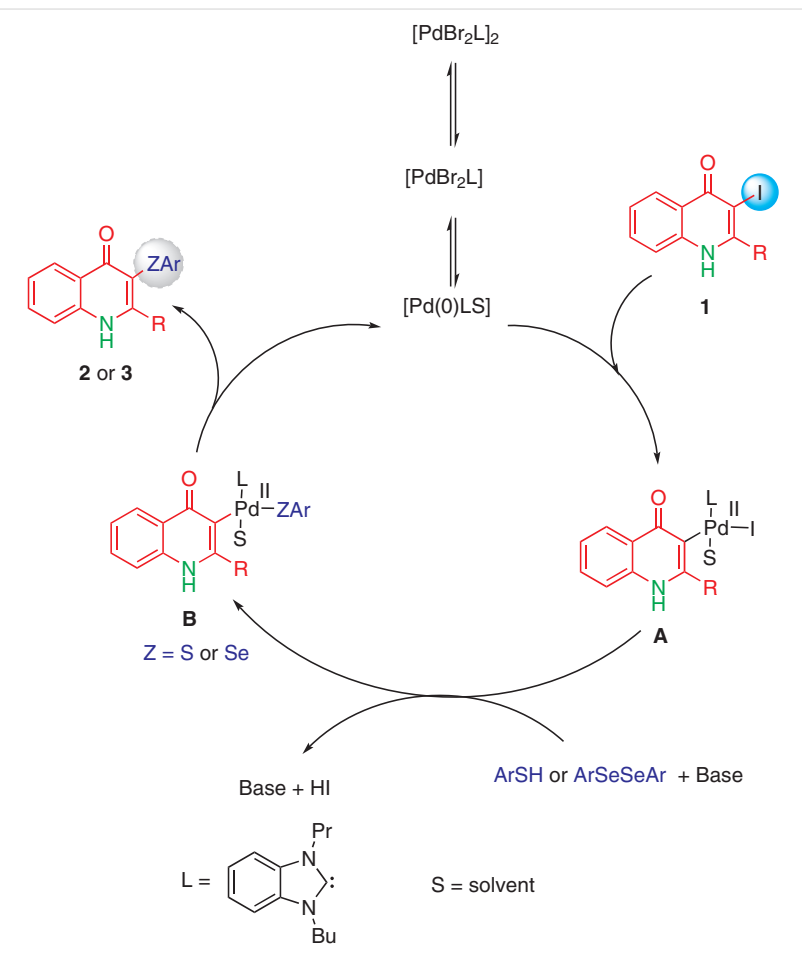

Scheme 4 Plausible mechanism of the Pd-NHC catalysed C-S/C-Se cross-coupling of 4-quinolone

In summary, we have revealed an alternative method for the synthesis of ipso-C-S and C-Se substituted 4-quinolone derivatives through $\mathrm{Pd}-\mathrm{NHC}$ catalysed cross-coupling reaction. ${ }^{19}$ This method should be attractive to the synthetic and pharmaceutical chemistry community for the library synthesis of 4-quinolone derivatives. Biological screenings of all compounds synthesised herein are under investigation in our laboratory.

\section{Funding Information}

We thank the DST, New Delhi for financial support (EMR/2016/001250).

\section{Supporting Information}

Supporting information for this article is available online at https://doi.org/10.1055/s-0039-1690897.

\section{References}

(1) (a) Beletskaya, I. P.; Ananikov, V. P. Chem. Rev. 2011, 111, 1596. (b) Mansy, S. S.; Cowan, J. A. Acc. Chem. Res. 2004, 37, 719. (c) Punniyamurthy, T. Chem. Rev. 2005, 105, 2329. (d) Kondo, T.; 
Mitsudo, T. Chem. Rev. 2000, 100, 3205. (e) Oida, S.; Tajima, Y.; Konosu, T.; Nakamura, Y.; Somada, A.; Tanaka, T.; Habuki, S.; Harasaki, T.; Kamai, Y.; Fukuoka, T.; Ohya, S.; Yasuda, H. Chem. Pharm. Bull. 2000, 48, 694. (f) Raghuvanshi, D. S.; Verma, N. RSC Adv. 2017, 7, 22860. (g) Qi, H.; Zhang, T.; Wan, K.; Luo, M. J. Org. Chem. 2016, 81, 4262. (h) Kumaraswamy, G.; Raju, R.; Narayanarao, V. RSC Adv. 2015, 5, 22718. (i) Li, J.; Cai, Z. J.; Wang, S. Y.; Ji, S. J. Org. Biomol. Chem. 2016, 14, 9384. (j) Gao, Z.; Zhu, X.; Zhang, R. RSC Adv. 2014, 4, 19891. (k) Yang, F. L.; Tian, S. K. Angew. Chem. Int. Ed. 2013, 52, 4929.

(2) (a) Kosugi, M.; Shimizu, T.; Migita, T. Chem. Lett. 1978, 13. (b) Migita, T.; Shimizu, T.; Asami, Y.; Shiobara, J.; Kato, Y.; Kosugi, M. Bull. Chem. Soc. Jpn. 1980, 53, 1385.

(3) Liu, G.; Huth, J. R.; Olejniczak, E. T.; Mendoza, F.; Fesik, S. W.; Von Genldern, T. W. J. Med. Chem. 2001, 44, 1202.

(4) Nielsen, S. F.; Nielsen, E. O.; Olsen, G. M.; Liljefors, T.; Peters, D. J. Med. Chem. 2000, 43, 2217.

(5) Pasquini, S.; Mugnaini, C.; Tintori, C.; Botta, M.; Trejos, A.; Arvela, R. K.; Larhed, M.; Witvrouw, M.; Michiels, M.; Christ, F.; Debyser, Z.; Corelli, F. J. Med. Chem. 2008, 51, 5125.

(6) De Martino, G.; La Regina, G.; Coluccia, A.; Edler, M. C.; Barbera, M. C.; Brancale, A.; Wilcox, E.; Hamel, E.; Artico, M.; Silvestri, R. J. Med. Chem. 2004, 47, 6120.

(7) (a) Santos, E. A.; Hamel, E.; Bai, R.; Burnett, J. C.; Tozatti, C. S.; Bogo, D.; Perdomo, R. T.; Antunes, A. M.; Marques, M. M.; Matos, M. F. C.; de Lima, D. P. Bioorg. Med. Chem. Lett. 2013, 23, 4669. (b) Milloisand, C.; Diaz, P. Org. Lett. 2000, 2, 1705. (c) Back, T. G.; Moussa, Z. J. Am. Chem. Soc. 2003, 125, 13455. (d) Andersson, C. M.; Hallberg, A.; Hogberg, T. Adv. Drug Res. 1996, 28, 65. (e) Clark, L. C.; Combs, G. F.; Turnbull, B. W.; Slate, E. H.; Chalker, D. K.; Chow, J.; Davis, L. S.; Glover, R. A.; Graham, G. F.; Gross, E. G.; Krongrad, A.; Lesher, J. L.; Park, K.; Sanders, B. B.; Smith, C. L.; Taylor, R. JAMA, J. Am. Med. Assoc. 1996, 276, 1957. (f) Engman, L.; Cotgreave, I.; Angulo, M.; Taylor, C. W.; Paine-Murrieta, G. D.; Powis, G. Anticancer Res. 1997, 17, 4599. (g) Goudgaon, N. M.; Naguib, F. N.; Kouni, M. H.; Schinazi, R. F. J. Med. Chem. 1993, 36, 4250. (h) Nedel, F.; Campos, V. F.; Alves, D.; McBride, A. J. A.; Dellagostin, O. A.; Collares, T.; Savegnago, L.; Seixas, F. K. Life Sci. 2012, 91, 345.

(8) (a) Nogueira, C. W.; Rocha, J. B. T. Arch. Toxicol. 2011, 85, 1313. (b) Nogueira, C. W.; Zeni, G.; Rocha, J. B. T. Chem. Rev. 2004, 104, 6255.

(9) (a) Nogueira, C. W.; Rocha, J. B. T. J. Braz. Chem. Soc. 2010, 21, 2055. (b) Muller, A.; Cadenas, E.; Graf, P.; Sies, H. Biochem. Pharmacol. 1984, 33, 3235. (c) Dawson, D. A.; Masayasu, H.; Graham, D. I.; Macrae, I. M. Neurosci. Lett. 1995, 185, 65. (d) Saito, I.; Asano, T.; Sano, K.; Takakura, K.; Abe, H.; Yoshimoto, T.; Kikuchi, H.; Ohta, T.; Ishibashi, S. Neurosurgery 1998, 42, 269. (e) Ogawa, A.; Yoshimoto, T.; Kikuchi, H.; Sano, K.; Saito, I.; Yamaguchi, T.; Yasuhara, H. Cerebrovasc. Dis. 1999, 9, 112.
(10) (a) Ajiki, K.; Hirano, M.; Tanaka, K. Org. Lett. 2005, 7, 4193. (b) Liao, Y.; Jiang, P.; Chen, S.; Qi, H.; Deng, G. J. Green Chem. 2013, 15, 3302. (c) Pandya, V. G.; Mhaske, S. B. Org. Lett. 2014, 16, 3836. (d) Sun, J.; Wang, Y.; Pan, Y. Org. Biomol. Chem. 2015, 13, 3878. (e) Yang, W.; Yang, S.; Li, P.; Wang, L. Chem. Commun. 2015, 51, 7520. (f) Zhang, S.; Qian, P.; Zhang, M.; Hu, M.; Cheng, J. J. Org. Chem. 2010, 75, 6732.

(11) Crumplin, G. C.; Midgley, J. M.; Smith, J. T. Top. Antibiot. Chem. 1980, 3,9 .

(12) Leonard, N. J.; Herbrandson, H. F.; Van Heyningen, E. M. J. Am. Chem. Soc. 1946, 68, 1279.

(13) Aimi, N.; Nishimura, M.; Miwa, A.; Hoshino, H.; Sakai, S.; Haginiwa, J. Tetrahedron Lett. 1989, 30, 4991.

(14) Boteva, A. A.; Krasnykh, O. P. Chem. Heterocycl. Compd. 2009, 45, 757.

(15) Huang, L. J.; Hsieh, M. C.; Teng, C. M.; Lee, K. H.; Kuo, S. C. Bioorg. Med. Chem. 1998, 6, 1657.

(16) Chengcai, X.; Zhenjiang, W.; Yong, Y.; Wenbo, Y.; Hanxiao, L.; Chao, S.; Pengfei, Z. Chem. Asian J. 2016, 11, 360.

(17) (a) Sarkar, S.; Ghosh, P.; Misra, A.; Das, S. Synth. Commun. 2015, 45, 2386. (b) Gupta, S.; Ghosh, P.; Dwivedi, S.; Das, S. RSC Adv. 2014, 4, 6254. (c) Ghosh, P.; Ganguly, B.; Das, S. Appl. Organomet. Chem. 2017, e4173. (d) Ghosh, P.; Nandi, A. K.; Das, S. Tetrahedron Lett. 2018, 59, 2025. (e) Ghosh, P.; Das, S. ChemistrySelect 2018, 3, 8624. (f) Ghosh, P.; Nandi, A. K.; Chhetri, G.; Das, S. J. Org. Chem. 2018, 83, 12411. (g) Ghosh, P.; Chhetri, G.; Nandi, A. K.; Sarkar, S.; Saha, T.; Das, S. New J. Chem. 2019, 43, 10959.

(18) (a) Gupta, S.; Basu, B.; Das, S. Tetrahedron 2013, 69, 122. (b) Gupta, S.; Ganguly, B.; Das, S. RSC Adv. 2014, 4, 41148.

(19) 2-Phenyl-3-(phenylthio)quinolin-4(1H)-one (2a); Typical Procedure: 3-Iodo-2-phenyl-substituted 4-quinolone (0.25 $\mathrm{mmol})$, thiophenol $(0.375 \mathrm{mmol})$, DBU $(0.5 \mathrm{mmol}, 76 \mathrm{mg})$ and Pd-NHC (0.5 mol\%, $1.2 \mathrm{mg}$ ) were dissolved in DMF ( $2 \mathrm{~mL})$ in a 25 $\mathrm{mL}$ round-bottomed flask and the mixture was heated to $80{ }^{\circ} \mathrm{C}$ for 1-2 $\mathrm{h}$. The mixture was then cooled, diluted with water, and the product was extracted with ethyl acetate $(3 \times 20 \mathrm{~mL})$. The combined organic extracts were dried over anhydrous $\mathrm{Na}_{2} \mathrm{SO}_{4}$, filtered and concentrated under reduced pressure. The crude product was then purified by column chromatography, eluting with petroleum ether/ethyl acetate to give the product as a white solid (mp 191-193 $\left.{ }^{\circ} \mathrm{C}\right) .{ }^{1} \mathrm{H}$ NMR $\left(300 \mathrm{MHz}\right.$, DMSO- $\left.d_{6}\right): \delta=$ 12.29 (s, $1 \mathrm{H}), 8.11$ (d, $J=7.8 \mathrm{~Hz}, 1 \mathrm{H}), 7.71-7.73(\mathrm{~m}, 2 \mathrm{H}), 7.48-$ $7.54(\mathrm{~m}, 5 \mathrm{H}), 7.41(\mathrm{~s}, 1 \mathrm{H}), 7.14-7.20(\mathrm{~m}, 2 \mathrm{H}), 6.97-7.05(\mathrm{~m}$, $3 \mathrm{H}) .{ }^{13} \mathrm{C}$ NMR $\left(75 \mathrm{MHz}\right.$, DMSO- $\left.d_{6}\right): \delta=175.5,139.9,138.8$, $135.5,132.8,130.2,129.1,129.0,128.5,125.9,125.5,124.8$, 124.7, 124.5, 119.2, 108.5. HRMS (ESI+): $m / z[\mathrm{M}+\mathrm{H}]^{+}$calcd for $\mathrm{C}_{21} \mathrm{H}_{16} \mathrm{NOS}$ : 330.0952; found: 330.0972 . 